\title{
EFIKASI DIRI SISWA DENGAN TANDA GEJALA PSIKOSIS AWAL DALAM MENCARI BANTUAN MELALUI USAHA KESEHATAN SEKOLAH JIWA
}

\author{
Ahmad Guntur Alfianto ${ }^{1)}$, Ayu Safitri ${ }^{2)}$ \\ Program Studi Ilmu Keperawatan, STIKES Widyagama Husada Malang; \\ email: 15589ahmadguntur@gmail.com
}

\begin{abstract}
Abstrak
Usaha Kesehatan Sekolah Jiwa (UKSJ) merupakan suatu layanan kesehatan jiwa berbasis sekolah. Program UKSJ terdiri dari pengkajian terjadi tanda gejala gangguan jiwa, pendidikan kesehatan dan yang terakhir empowerment. Tujuan dari UKSJ iyalah meningkatkan pengetahuan dan perilaku siswa tentang gangguan jiwa. TujuanMenganalisis pengaruh UKSJ terhadap efikasi diri dalam mencari bantuan tanda gejala psikosis awal. Metode Penelitiananalisis eksperimen dengan pendekatan quasi experiment dan tekhnik total sampling pada siswa SMK di Bantur dengan menggunakan kuesioner General self efficacy (GSE). Hasilanalisis uji $t$ berpasangan menunjukkan adanya perbedaan yang bermakna pada kelompok intervensi nilai $(p=0.000)$ dan tidak ada perbedaan yang bermakna pada kelompok control (pedidikan kesehatan dengan leaflet) dengan nilai $(p=0.805)$.Kesimpulan Terdapat pengaruh Usaha Kesehatan Sekolah Jiwa (UKSJ) terhadap efikasi diri remaja dalam mencari bantuan tanda gejala psikosis awal dan tidak terdapat penegaruh pada kelompok kontrol.
\end{abstract}

Kata Kunci :Usaha Kesehatan Sekolah Jiwa, pengetahuan, mencari bantuan, tanda gejala psikosis awal.

\begin{abstract}
School Mental Health (SMH) is a school-based mental health service. The School Mental Health program consists of assessing mental symptoms, health education and empowerment at the school. The purpose of SMH is to improve students' knowledge and behavior about mental disorders. The purpose of the study is to analyze the effect of SMH on Self efficacy in help seeking for adolescents with the symptoms of early psychosis. Research Methods is: Analytical experiments with a quasi-experimental approach and sample techniques by using total sampling at 108 the students of Vocational High Schools (SMK) in Bantur Malang. The instruments using General Self Efficacy (GSE). The results of paired $T$ test analysis showed an influence on the intervention group (School Mental Health) value $(p=0.000)$ and no influence on the control group (leaflet health education) with a value ( $p=0,805)$. Conclusion: There is an effect of School Mental Health on Self efficacy in help seeking in adolescents with early psychosis symptoms of and there is no effect on the control group.
\end{abstract}

Keywords : School Mental Health, self efficacy, help seeking, early psychosis symptoms

\section{PENDAHULUAN}

Psikosis awal merupakan suatu tanda gejala yang di tandai dengan pikiran, persepsi dan perilaku yang menyimpang. Psikosis selalu diawali dengan fase prodomal, fase tersebut di tandai dengan gejala non psikotik seperti kemampuan berkonsentrasi menurun, penurunan motivasi, depresi, cemas, gangguan pola tidur, dan sosial (McClellan, 2018).

Remaja yang mengalami psikosis awal disebabkan oleh beberapa faktor seperti keturunan, kognitif, disfungsi sosial yang buruk, trauma dimasa lalu, hingga stress dikarnakan trauma juga menimbulkan kerentanan pada individu untuk mengalami psikosis awal (Thompson, Kline, Reeves, Pitts, \& Schiffman, 
2013). Efikasi diri remaja terhadap psikosis awal dan cara pengobatan serta mencari bantuan sangatlah rendah, sehingga remaja sangat mengabaikan terhadap kesehatan jiwanya (Umubyeyi, Mogren, Ntaganira, \& Krantz, 2016).

Remaja yang mengalami psikosis awal sangat penting dalam mencari bantuan. Bantuan tersebut dapat berupa dukungan dari keluarga, teman sebaya hingga tenaga kesehatan. Bantuan awal yang dapat di lakukan dengan tepat dapat mengurangi tanda dan gejala psikosis awal (Kline et al., 2016). Tahapan dalam mencari bantuan yang dilakukan oleh remaja pertama kali akan mengenali masalahnya, kemudian remaja akan mengambil keputusan dalam mencari bantuan dan menentukan bantuan yang akan dituju oleh remaja tersebut (Heerde \& Hemphill, 2018).

Prevalensi terjadinya psikosis di Indonesia adalah 7,0\% dan Provinsi Jawa Timur memiliki prevalansi kejadian psikosis sebesar 3,0\%. Tanda gejala psikosis awal antara lain penduduk Indonesia mengalami depresi di usia lebih dari 15 tahun sebanyak $6,1 \%$, penduduk Indonessia mengalami gangguan emosional dengan usia lebih dari 15 tahun sebesar 9,8\%. Penduduk Indonesia yang mengalami psikosis awal yang tidak melakukan pengobatan sebesar 91\% (Kemenkes RI, 2018). Hasil studi di salah satu SMK di Kecamatan Bantur kabupaten Malang hampir 45\% siswa pernah mengalami masalah tanda gejala psiksosis awal. Tanda gejala psikosis awal terbanyak adalah kasus gangguan emosiaonal cemas. Selain itu ratarata $30 \%$ siswa jika mengalami masalah tanda gejala psikosis awal hanya bercerita kepada teman sebayanya sisanya $70 \%$ tidak tahu dalam mencari bantuan.

Upaya yang sudah dilakukan di SMK Tersebut salah satunya dibentuk Usaha Kesehatan Sekolah Jiwa (UKSJ). Upaya tersebut untuk meningkatkan kesehatan jiwa di sekolah. Kegiatan yang di laksanakan di SMK Tersebut dalam upaya meningkatakn kesehatan jiwa adalah penyuluhan tentang kesehatan jiwa remaja dan pelatihan deteksi dini pada guru untuk siswanya yang mengalami masalah psikososial. Usaha kesehatan sekolah jiwa merupakan kegiatan yang terintegrasi di lingkungan sekolah dalam mengurangi masalah kesehatan jiwa di sekolah. Tujuan utama dari usaha kesehatan sekolah jiwa memberikan perubahan pada stigma dan tingkat diskriminasi pada remaja yang mengalami masalah kesehatan jiwa (SchulteKörne, 2016). Oleh sebab itu penelitian ini menganalisis pengaruh program UKSJ dalam meningkatkan efikasi diri mencari bantuan pada remaja dengan tanda gejala psikosis awal.

\section{METODE}

Penelitian ini menggunaka pendekatanquasi experimentalpre-post control group. Penelitian dilakukan di salah satu SMK di Kecamatan Bantur Kabupaten Malang dengan waktu penelitian mulai bulan Mei hingga Juli 2019. Sampling yang di gunakan dengan pendekatan total sampling dengan kriteria inklusi remaja usia 15-24 tahun, responden yang pernah mengalami masalah psikososial 1 tahun terakhir. Responden tidak mengalami gangguan jiwa. Responden dalam penelitian ini berjumlah $n=108$ orang yang terbagi menjadi kelompok intervensi (usaha kesehatan sekolah jiwa) dan kelompok kontrol (pendidikan kesehatan).

Penelitian dilakukan dengan pemberian pretest pada kelompok UKSJ dan pada kelompok kontrol kemudian diukur kembali dengan posttest. Intervensi UKSJ dilakukan menjadi 3 sesi. Sesi pertama dilakukan pengkajian terhadap masalah psikososial dan usaha yang dilalakukan oleh responden, sesi kedua pendidikan kesehatan terkaiattanda gejala psikosis awal, sesi ketiga pemberdayaan dalam mencari bantuan jika terjadi masalah psikosis awal. Instrumen dalam penelitian ini menggunakan kuesioner general self efficacyscale (GES) dengan nilai cronbach's alphas antara 0,76 hingga 0,90 (Schwarzer \& Jerusalem, 2010). Kuesioner tersebut berjumlah 10 pertanyaan dengan skala likertdan pilihan jawaban sangat setuju (ST), setuju (T), tidak setuju (TS), dan sangat tidak setuju (STS) . Skor nilai GES adalah 10-40. Dimensi dari instrumen GES adalah level, strength, generality dengan indikator keyakinan individu dalm mengalami tugas, pemilihan tingkah laku, pengharapan dalam kemampuan dan kayakinan individu dalam melakukan tugas tersebut sebagai aktivitas. 
Instrumen GES di terjemahkan kedalam bahasa Indonesia oleh ahli bahasa Inggris, instrument tersebut di uji validitas dan reliabilitas dilakukan di salah satu SMK di kali pare dengan jumlah 30 responden dan hasil nilai cronbach's Alpha sebesar
0,381. Uji statsitik pada penelitian ini menggunakan Statistical Product and Service Solutions (SPSS) 25 dan uji hipotesis dalam penelitian ini menggunakan paired T test.

\section{HASIL}

Tabel 1. Analisia Karakteristik Responden Siswa SMK di Kecamatan Bantur dengan Tanda Gejala Psikosis Awal

\begin{tabular}{cccccc}
\hline \multirow{2}{*}{$\begin{array}{c}\text { Karakteristik } \\
\text { Responden }\end{array}$} & \multicolumn{2}{c}{$\begin{array}{c}\text { Kelompok intervensi } \\
\text { (Usaha Kesehatan Sekolah Jiwa) }\end{array}$} & \multicolumn{2}{c}{$\begin{array}{c}\text { Kelompok kontrol } \\
\text { (pendidikan kesehatan) }\end{array}$} \\
\cline { 2 - 6 } & Kategori & $\begin{array}{c}\text { Frekuensi } \\
\text { (n) }\end{array}$ & $\begin{array}{c}\text { Persen } \\
(\%)\end{array}$ & Frekuensi (n) & Persen (\%) \\
\hline Usia & $15-18$ & 22 & 41 & 18 & 33 \\
& $16-24$ & 32 & 59 & 36 & 67 \\
Jenis Kelamin & Laki-laki & 19 & 35 & 26 & 48 \\
& Perempuan & 35 & 65 & 28 & 52 \\
Masalah & Cemas & 44 & 81 & 45 & 54 \\
psikososial 1 & Susah tidur & 2 & 4 & 3 & 4 \\
tahun terakhir & Sulit berfikri & 5 & 11 & 2 & 7 \\
\hline
\end{tabular}

Uji homogenitas dan normalitas pada penelitian ini data menggunakan uji Levine dan analisis Kolmogrorov-Smirnof. Hasil uji Levine dari nilai pretest dan posttest setiap variable dependennya antara lain kelompok UKSJ dan kelompok kontrol dengan variable efikasi diripretest nilainya (0.133). posttestefikasi diri kelompok UKSJ dan kelompok kontrol nilainya (0.279). Sehingga kedua kelompok tersebut memiliki nilai varian yang sama (homogen).
Hasil analisis kolmogrov- Smirnof adalah variable pengetahuan kelompok intervensi adalah pretest (0.198), variabel efikasi diri pada kelompok kontrol nilai pretest (0.071), variabel efikasi diri pada kelompok UKSJ nilai posttest sebesar (0.082) dan variabel efikasi diri nilai posttest pada kelompok kontrol sebesar (0.075). Sehingga data tersebut berdistribusi normal dan di lakukan uji paired $t$ Test.

Tabel 2. Uji Perbedaan Efikasi Diri dalam Mencari Bantuan pada Siswa dengan Tanda dan Gejala Psikosis Awal Sebelum dan Setelah di Berikan Usaha Kesehatan Sekolah Jiwa

\begin{tabular}{lcccc}
\hline Kelompok & Variabel & Rerata & $\boldsymbol{t}$ & $\boldsymbol{p}$ \\
\hline Kelompok intervensi & & & & \\
Pretest intervensi & Efikasi diri & 24,44 & 8,36 & 0,000 \\
$\begin{array}{l}\text { Posttest intervensi } \\
\text { Kelompok kontrol }\end{array}$ & 32,78 & & \\
Pretest control & Efikasi diri & 23,30 & 0,09 & 0,805 \\
Posttest control & & 23,39 & & \\
\hline
\end{tabular}


Tabel 1 merupakan karakteristik responden SMK di Kecamantan Bantur Kabupaten Malang. Kalateristik tersebut terdiri dari variable usia, jenis kelamin dan masalah psikososial 1 tahun terakhir. Sedangkan table 2 merupakan uji perbedaan efikasi diri siswa dalam mencari bantuan dalam masalah tanda dan gejala psikosis awal sebelum dan setelah diberikan UKSJ hasilnya adalah kelompok UKSJ sebesar 0,001 $(\mathrm{p}<0,05)$ sedangkan pada kelompok kontrol sebesar $0,052(\mathrm{p}>0,05)$.

\section{PEMBAHASAN}

Penelitian ini menunjukkan bahwa terdapat pengaruh UKSJ terhadap efikasi diri mencari bantuan pada Siswa yang mengalami masalah psikosis awal. Sebaliknya pada kelompok kontrol tidak terdapat pengaruh pendidikan kesehatan dengan pemberian lealflet terhadap efikasi diri dalam mencari bantuan pada remaja dengan masalah tanda gejala psikosis awal. Efikasi diri menurut Bandura adalah kemampuan dan kepercayaan yang di yakini oleh seseorang dalam melaukan aktivitas sehari-hari(Flammer, 2015).

Objek dalam penelitian ini adalah UKSJ yang di dalamnya terdapat pengkajian kesehatan jiwa, pendidikan kesehatan dan pemberdayaan. Tahapan usaha kesehatan sekolah jiwa juga dilakukan dengan deteksi dini pada remaja yang memiliki perilaku agresif, pendidikan keseahtan pada remaja yang mengalami agresif, serta remaja mampu melatih manjemen stres dan emosi (Green et al., 2013). Penelitian tersebut juga sejalan dengan Penelitian tentang sekolah sehat jiwa di Negara Kanada yang lebih menekankan terhadap fasilitas bantuan dalam mengurangi masalah keseahatan jiwa di Negara tersebut

\section{REFERENSI}

Flammer, A. (2015). Self-Efficacy. In International Encyclopedia of the Social \& Behavioral Sciences: Second Edition. https://doi.org/10.1016/B978-0-08-0970868.25033-2
(Mental Health Commission of Canada, 2013). Penelitian ini tidak mengikutsertakan guru serta kurikulum sekolah dalam pengembangnya, seharusnya dalam program UKSJ harus di kembangkan bersama guru, siswa serta kurikulum yang terdapat di sekolahan tersebut (Kutcher et al., 2016). Guru sebagai pemberi kebijakan terkait masalah sekolah juga memberikan dampak yang baik kepada siswa terakait kesehatan jiwa. Salah satunya membentuk kesehatan jiwa di sekolah dengan mengembangkan kolaborasi dengan tenaga kesehatan, memberikan intervensi sedini mungkin terhadap masalah kesehatan jiwa (Franklin, Kim, Ryan, Kelly, \& Montgomery, 2012).

UKSJ diharapkan dapat dilakukan oleh semua sumberdaya yang ada disekolah tersebut, mulai dari guru, siswa, guru konseling hingga kebijakan dan kurikulum dalam meningkatkan program kesehatan jiwa disekolah. Sehingga komponen yang mendukung keberhasilan sekolah sehat jiwa mampu meningkatakn efikasi diri sisiwa dalam mencari bantuan jika terjadi masalah psikosis awal.

\section{KESIMPULAN}

Penelitian ini dapat disimpulkan bahwa terdapat pengaruh UKSJ terhadap efikasi diri mencari bantuan pada remaja dengan tanda gejala psikosis awal. Tidak terdapat pengaruh pada kelompok kontrolterhadap efikasi diri mencari bantuan pada remaja dengan tanda gejala psikosis awal di salah satu SMK di Kecamatan Bantur.

Franklin, C. G. S., Kim, J. S., Ryan, T. N., Kelly, M. S., \& Montgomery, K. L. (2012). Teacher involvement in school mental health interventions: A systematic review. Children and Youth Services Review. https://doi.org/10.1016/j.childyouth.2012.01.027 
Green, J. G., McLaughlin, K. A., Alegría, M., Costello, E. J., Gruber, M. J., Hoagwood, K., ... Kessler, R. C. (2013). School mental health resources and adolescent mental health service use. Journal of the American Academy of Child and Adolescent Psychiatry. https://doi.org/10.1016/j.jaac.2013.03.002

Heerde, J. A., \& Hemphill, S. A. (2018). Examination of associations between informal help-seeking behavior, social support, and adolescent psychosocial outcomes: A metaanalysis. Developmental Review. https://doi.org/10.1016/j.dr.2017.10.001

Kemenkes RI. (2018). Hasil Utama Riset Kesehatan Dasar Tahun 2018. Kementrian Kesehatan Republik Indonesia. https://doi.org/1 Maret2019

Kline, E., Millman, Z. B., Denenny, D., Wilson, C., Thompson, E., Demro, C., ... Schiffman, J. (2016). Trauma and psychosis symptoms in a sample of help-seeking youth. Schizophrenia Research.

https://doi.org/10.1016/j.schres.2016.04.006

Kutcher, S., Wei, Y., Gilberds, H., Ubuguyu, O., Njau, T., Brown, A., ... Perkins, K. (2016). A school mental health literacy curriculum resource training approach: Effects on Tanzanian teachers' mental health knowledge, stigma and help-seeking efficacy. International Journal of Mental Health Systems. https://doi.org/10.1186/s13033-016-0082-6
McClellan, J. (2018). Psychosis in Children and Adolescents. Journal of the American Academy of Child and Adolescent Psychiatry. https://doi.org/10.1016/j.jaac.2018.01.021

Mental Health Commission of Canada. (2013). School-based mental health in Canada: a final report. Santé mentale en milieu scolaire au Canada : rapport final.

Schulte-Körne, G. (2016). Mental Health Problems in a School Setting in Children and Adolescents. Deutsches Aerzteblatt Online. https://doi.org/10.3238/arztebl.2016.0183

Schwarzer, R., \& Jerusalem, M. (2010). The general self-efficacy scale (GSE). Dostupné $z$ : Http://Userpage. Fu-Berlin. de/ Health/Engscal. Htm.

Thompson, E., Kline, E., Reeves, G., Pitts, S. C., \& Schiffman, J. (2013). Identifying youth at risk for psychosis using the Behavior Assessment System for Children, Second Edition. Schizophrenia Research. https://doi.org/10.1016/j.schres.2013.09.022

Umubyeyi, A., Mogren, I., Ntaganira, J., \& Krantz, G. (2016). Help-seeking behaviours, barriers to care and self-efficacy for seeking mental health care: a population-based study in Rwanda. Social Psychiatry and Psychiatric Epidemiology. https://doi.org/10.1007/s00127015-1130-2 